\title{
HUKUM YANG BERKEADILAN BAGI PENYANDANG DISABILITAS
}

\author{
RR. Putri A. Priamsari \\ Kejaksaan Negeri Temanggung \\ Jl. Letjend. Suprapto No. 40, Gendongan, Temanggung II, Kec. Temanggung, \\ Kabupaten Temanggung, Jawa Tengah 56213 \\ priamsari69aiu@gmail.com
}

\begin{abstract}
As a legal state, it has become imperative for the State of Indonesia to protect the rights of persons with disabilities, as one of the constitutional rights as stipulated in article 28 paragraph (2) of the 1945 Constitution of the Republic of Indonesia. This writing aims to see whether the current law in Indonesia has been able to realize justice for Disabled Persons, this embodiment includes aspects of the readiness of the Government and Apparatus and Law Enforcement Institutions in an effort to present justice laws for persons with disabilities both in their positions as witnesses, victims and perpetrators of criminal acts, and what are the consequences of not passing the Government Regulation as the implementing rule of Law No. 8 of 2016 concerning Persons with Disabilities.
\end{abstract}

Keywords : law; justice; disabilities

\begin{abstract}
Abstrak
Sebagai negara hukum, sudah menjadi keharusan bagi Negara Indonesia untuk melindungi hak-hak para Penyandang Disabilitas, sebagai salah satu hak konstitusional (constitutional right) sebagaimana yang diatur dalam Pasal 28 I ayat (2) UUD Negara Republik Indonesia Tahun 1945. Penulisan ini bertujuan untuk melihat apakah hukum yang berlaku di Indonesia sekarang ini telah mampu mewujudkan keadilan bagi para Penyandang Disabilitas, perwujudan ini mencakup aspek kesiapan Pemerintah serta Aparat dan Institusi Penegak Hukum dalam upaya menghadirkan Hukum yang berkeadilan bagi para Penyandang Disabilitas baik dalam kedudukannya sebagai saksi, korban maupuan pelaku tindak pidana, dan bagaimanakah konsekwensi dari belum disahkannya Peraturan Pemerintah sebagai aturan pelaksana Undang-Undang No. 8 Tahun 2016 tentang Penyandang Disabilitas.
\end{abstract}

Kata kunci : Hukum; Keadilan; Penyandang Disabilitas

\section{A. Pendahuluan}

Manusia sebagai makhluk ciptaan Allah SWT mempunyai harkat, martabat (dignity) dan kedudukan yang sama dimuka bumi, baik yang terlahir sempurna maupun dalam kondisi disabilitas. Ketidaksempurnaan itu tidak boleh menjadi penyebab hilangnya harkat dan martabat penyandang disabilitas. Namun kenyataannya, penyandang disabilitas seringkali menjadi kelompok yang paling rentan dan termajinalkan dalam kehidupan sosial.

Indonesia, sebagai Negara yang bermartabat sangat menghormati, menghargai, memenuhi dan memberikan perlindungan bagi setiap warga negaranya tanpa kecuali. Hal ini tersurat dalam Pasal 5 ayat (1), Pasal 11, Pasal 20, dan Pasal 28 I ayat (2) Undang-Undang Dasar Negara Republik Indonesia Tahun 1945.

Sejalan dengan ketentuan tersebut, salah satu prinsip penting adalah adanya jaminan kesamaan derajat bagi setiap orang dihadapan hukum. Oleh karena itu, setiap orang berhak atas pengakuan, jaminan, perlindungan, dan kepastian hukum yang adil, serta perlakuan yang sama dihadapan hukum "Equality Before the Law". 
UUD Negara Republik Indonesia tahun 1945 Pasca Amendemen mencantumkan Bab XA yang membahas perihal Hak Asasi Manusia. Bab inilah yang kemudian menjadi bentuk nyata dari perlindungan hak konstitusional Warga Negara secara umum, termasuk Warga Negara penyandang disabilitas, di dalamnya terdapat 10 pasal, yaitu Pasal 28A sampai dengan Pasal 28J, yang mencakup 26 ketentuan yang tersurat di dalam ayat-ayat dan pasal-pasal yang ada. Keseluruhan ketentuan itu dapat dibagi menjadi dua jenis, yaitu perlindungan HAM khusus bagi Warga Negara dan perlindungan HAM bagi Setiap Orang, yang berarti tidak hanya Warga Negara Indonesia saja.

Adanya pengklasifikasian yang terbagi hanya pada 2 kelompok besar saja, melahirkan makna bahwa para penyandang disabilitas secara langsung/tidak langsung sudah termaktub didalamnya. Dari 26 ketentuan yang ada pada Bab XA tersebut, terdapat satu pasal yang mengatur perihal perlindungan khusus bagi penyandang disabilitas, yaitu Pasal $28 \mathrm{H}$ ayat (2) yang menyatakan bahwa, "setiap orang berhak mendapat kemudahan dan perlakuan khusus untuk memperoleh kesempatan dan manfaat yang sama guna mencapai persamaan dan keadilan". Ketentuan Pasal tersebut jelas menggunakan istilah "setiap orang" tanpa dipersyaratkan adanya keadaan atau kondisi tertentu dari subjek hukum yang dimaksud.

Selain itu, terdapat 3 putusan Mahkamah Konstitusi terkait dengan pengertian "setiap orang" dalam pasal tersebut, yaitu ${ }^{1}$ : Putusan MK Nomor 10-17-23/PUU-VII/2009; Putusan MK Nomor 143/PUU-VII/2009; dan Putusan MK No. 16/PUU-VIII/2010. Dalam ketiga Putusan itu, MK menyatakan bahwa, "hak konstitusional dalam Pasal 28H ayat (2) UUD 1945 adalah jaminan konstitusional terhadap mereka yang mengalami peminggiran, ketertinggalan, pengucilan, pembatasan, pembedaan, kesenjangan partisipasi dalam politik dan kehidupan publik yang bersumber dari ketimpangan struktural dan sosio-kultural masyarakat secara terus menerus

\footnotetext{
${ }^{1}$ Fajri Nursyamsi, Estu Dyah Arifianti, Muhammad Faiz Aziz, Putri Bilqish dan Abi Marutama, (2015). Kerangka Hukum Disabilitas di Indonesia : Menuju
}

(diskriminasi), baik formal maupun informal, dalam lingkup publik maupun privat atau yang dikenal dengan affirmative action."

Tahun 2011, Indonesia telah meratifikasi Convention on the Rights of Persons with Disabilities (selanjutnya disingkat CRPD) yaitu konvensi tentang Hak-hak Difabel/Penyandang Disabilitas, dengan diterbitkannya UndangUndang Negara Republik Indonesia Nomor 19 Tahun 2011 tentang Pengesahan CRPD. CRPD merupakan instrument HAM internasional dan nasional dalam upaya penghormatan, pemenuhan dan perlindungan Hak difabel di Indonesia (Development tool and Human Rights Instrument).

Tahun 2016, Rapat Paripurna Dewan Perwakilan Rakyat pada Kamis, 17 Maret 2016, menyepakati RUU Penyandang Disabilitas menjadi UU Penyandang Disabilitas sebagai pemenuhan hak penyandang disabilitas baik hak ekonomi, politik, sosial dan budaya maupun kesetaraannya di mata hukum. Terbitnya UU ini diharapkan menjadi payung perlindungan hukum bagi setiap orang, khususnya bagi penyandang disabilitas agar terhindar dari segala bentuk ketidak adilan, kekerasan dan diskriminasi.

Tahun 2018, tepatnya pada 6 Oktober 2018 yang lalu, Indonesia dipercaya menjadi tuan rumah penyelenggaraan Pesta Olah Raga Difabel Asia Tenggara (ASEAN Para Games) yang merupakan ajang olah raga yang khusus diperuntukan bagi atlet-atlet yang mengalami cacat fisik (difabel). Begitu terhormat dan dihargainya para penyandang disabilitas tidak saja dalam kedudukannya secara personal namun juga perannya sebagai subjek hukum, menuntut pemerintah untuk lebih fokus dan konsisten dalam mendukung penyelenggaraan penerapan hukum ramah disabilitas.

Dua tahun telah berlalu sejak UU No. 8 tahun 2016 tentang Penyandang Disabilitas disahkan, namun hingga kini, Peraturan Pemerintah/PP sebagai peraturan pelaksana untuk menjalankan UU Disabilitas, belum juga disahkan. Hal ini membawa konsekwensi bagi para penyandang disabilitas

Indonesia Ramah Disabilitas, Jakarta : Pusat Studi Hukum dan Kebijakan Indonesia, Hlm. 23. 
dalam kedudukannya baik itu sebagai korban, saksi maupun pelaku.

Problematika yang kemudian muncul adalah, apakah pemerintah, aparat dan institusi penegak hukum telah mampu untuk mewujudkan hukum yang berkeadilan bagi para penyandang disabilitas dan apa yang menjadi konsekwensi dalam hal belum disahkannya peraturan pemerintah sebagai aturan pelaksana UU Disabilitas sementara UU telah di Undangkan dan hukum acara tetap berjalan.

\section{B. Hasil dan Pembahasan}

1. Kesiapan Pemerintah, Aparat dan Institusi Penegak Hukum dalam Mewujudkan Hukum yang Berkeadilan Bagi Para Penyandang Disabilitas

Dalam rangka untuk mewujudkan kesamaan hak tanpa diskriminasi bagi penyandang disabilitas, Indonesia telah meratifikasi Konvensi sebagaimana yang telah dikemukakan diatas. Hal ini berarti bahwa pemerintah hendak memberikan sebuah penekanan, yaitu Negara harus mengambil langkah positif agar hak para penyandang disabilitas dapat dipenuhi dan dilindungi secara hukum.

Berikut beberapa contoh pengaturannya dalam UU Disabilitas tahun 2016 :

a. Pasal 5 ayat (3) menyatakan "Penyandang Disabilitas anak berhak diberikan perlindungan khusus meliputi hak mendapatkan perlindungan lebih dari tindak kekerasan dan kejahatan seksual."

b. Pasal 9 menyebutkan bahwa "Penyandang Disabilitas Penyandang Disabilitas berhak memperoleh penyediaan aksesibilitas dalam pelayanan peradilan."

c. Pasal 30 ayat (1) Penyandang Disabilitas, berbunyi "Penegak hukum sebelum memeriksa Penyandang Disabilitas sebagai saksi, tersangka, terdakwa atau korban wajib meminta pertimbangan atau saran dari dokter, psikolog, psikiater, atau tenaga ahli profesional untuk mengetahui kondisi kesehatan atau kejiwaan Penyandang Disabilitas."

d. Pasal 36 berbunyi, "Lembaga Penegak hukum wajib menyediakan akomodasi yang layak bagi Penyandang Disabilitas dalam proses peradilan."

e. Pasal 37 mengatur tentang, "Kewajiban Rumah Tahanan Negara dalam menyediakan Unit Layanan Disabilitas".

Namun demikian, sejauh ini pemerintah masih belum mampu membuat pengaturan untuk mengakomodasi secara prosedural dan penyesuaian usia bagi penyandang disabilitas. Pemerintah sepatutnya mempertimbangkan ketersediaan fasilitas bagi penyandang difabel yang berperan aktif termasuk sebagai saksi, untuk mendapatkan pedampingan atau penerjemah, mendapat fasilitas yang aksesibel dalam bentuk ketersediaan alat media, sarana, dan prasarana yang dibutuhkan dalam proses persidangan, termasuk sejak pada tahap penyidikan dan tahap-tahap awal lainnya.

Selain itu, dalam rangka menolong terjaminnya akses efektif bagi penyandang disabilitas, Negara seharusnya mulai mempertimbangkan untuk membekali para pegawai pelaksana yang bekerja dibidang penyelenggaraan hukum termasuk polisi, pengawal tahanan dan sipir penjara, dengan keterampilan khusus melalui pelatihan yang sesuai, sehingga dapat terintegrasi dengan sistem hukum acara peradilan pidana.

Selain itu, alangkah lebih apiknya apabila pengaturan Aspek criminal justice yang terkandung di dalam UU Penyandang Disabilitas dapat berjalan searah dengan ketentuan RKUHAP atau setidaknya, apabila RKUHAP masih belum dapat mengakomodir kebutuhan dan kepentingan penyandang disabilitas, seharusnya pengaturan UU Penyandang Disabilitas sebagai lex specialist dapat lebih progresif dalam menghadirkan terobosan untuk melengkapi apa yang tidak dapat dijangkau oleh RKUHAP.

Mengingat lembaga peradilan, baik Polisi, Jaksa atau Hakim sebagai Aparat Penegak Hukum dalam menjalankan proses sistem peradilan pidana akan mengacu pada RKUHAP, maka UU Disabilitas idealnya harus mulai mempunyai dua fungsi utama yaitu sebagai sosial kontrol dan sebagai rekayasa sosial (a tool of social control and a tool of social 
engineering $)^{2}$. Sehingga eksistensi CRPD dalam perspektif hukum dan Hak Asasi Manusia dalam arti universal, bagi penyandang disabilitas, mampu menjadi sarana kontrol yang mendasari semua peraturan hukum maupun kebijakan yang selama ini belum mengakomodir perlindungan dan pemenuhan hak bagi penyandang disabilitas.

Selain itu, yang terpenting adalah paradigma para penegak hukum yang seharusnya memandang para penyandang disabilitas sebaiknya diperlakukan sebagai orang yang memiliki hak yang setara dengan manusia yang lain, mampu mengklaim haknya (human right based) dan tidak menggunakan cara pandang lama yang melihat para penyandang disabilitas hanya sebagai "obyek" amal, yang patut dikerdilkan dan dikasihani sebatas pengobatan dan perlindungan sosial (charity atau social based).

Dari segi penegakan hukum, penyandang disabilitas juga berhak atas proses peradilan yang fair, sebagaimana tersebut dalam Pasal 14 International Covenant on Civil and Political Rights. Dimana pasal ini berisi jaminan prosedural (procedural guarantee) agar peradilan berjalan dengan baik dan fair. Beberapa kekhususan yang harus diperhatikan pada proses peradilan bagi penyandang disabilitas adalah kebutuhan ketersediaan layanan peradilan yang berbeda dengan orang pada umumnya. Ketersediaan layanan ini berkaitan dengan dua hal, yaitu aksesibilitas fisik dan aksesibilitas prosedural. ${ }^{3}$

Aksesibilitas fisik berkaitan dengan kewajiban peradilan untuk memastikan bahwa sarana fisik seperti gedung pengadilan, tempat parkir, ruang tunggu, ruang sidang, toilet, ruang pelayanan publik lainnya, berkas acara pemeriksaan, surat dakwaan, tuntutan dan putusan, memiliki karakteristik yang aksesibel bagi penyandang disabilitas.

\footnotetext{
2 Supriyadi Widodo Eddyono dan Ajeng Gandini Kamilah, (2015). Aspek - Aspek Criminal Justice Bagi Penyandang Disabilitas, Jakarta : Institute for Criminal Justice Reform, Hlm. 24.

${ }^{3}$ Kata Pengantar oleh Suparman Marzuki, Proses Peradilan Harus Menjamin Aksesibilitas Bagi Penyandang Disabilitas, dalam Hari Kurniawan, dkk, Aksesibilitas Peradilan Bagi Penyandang Disabilitas, Yogyakarta : Pusham UII, 2105, Hlm. xv.
}

Sedangkan aksesibilitas prosedural berkaitan dengan hukum acara yang pada beberapa pengaturannya masih membatasi akses bagi penyandang disabilitas, seperti ketentuan mengenai "Saksi”. Dimana saksi dimaknai secara "limitatif" terbatas hanya pada orang yang mengalami, melihat dan mendengar sendiri adanya suatu peristiwa, hal ini akan sangat sulit dipenuhi bagi penyandang disabilitas dengan disfungsi netra dan tuli. ${ }^{4}$

Cara pandang sosial masyarakat termasuk para penegak hukum yang masih meletakkan penyandang disabilitas sebagai kelompok yang lemah. Menyebutnya dengan kata-kata cacat seolah-olah meletakkan kesalahan secara pribadi kepada penyandang disabilitas, padahal kekurang sempurnaan fisik tersebut bukanlah kesalahan dan tentu saja bukan sesuatu yang dikehendaki.

Masih banyak Aparat Penegak Hukum yang memiliki paradigma bahwa istilah penyandang cacat memiliki makna ideologis yang berarti ketidakmampuan, invalid, dalam arti tidak normal atau tidak menjadi manusia seutuhnya dan penuh kekurangan. ${ }^{5}$

Bila di teliti lebih dalam, ternyata RKUHAP belum memiliki ketentuan dan prosedur yang jelas mengatur tentang penanganan kasus hukum yang menimpa penyandang disabilitas. ${ }^{6}$ Di dalam RKUHAP, hanya terdapat dua pasal yang mengatur tentang hak-hak penyandang disabilitas, yaitu Pasal 91 ayat (2) dan Pasal 168 ayat (1) dan (2) RKUHAP.

Pasal 91 ayat (2) berbunyi: "Dalam hal tersangka atau terdakwa buta, bisu, atau tuli diberikan bantuan sesuai dengan ketentuan sebagaimana dimaksud dalam Pasal 168."

Pasal 168 ayat (1) berbunyi: "Jika terdakwa atau saksi bisu, tuli, atau tidak dapat menulis, Hakim Ketua

${ }^{4}$ Ibid. hlm. xvi.

5 Mansour Fakih, Jalan Lain : Manifesto Intelektual Organik (Yogyakarta : Pustaka Pelajar, 2011), hlm. 306-307.

6 http://pantaukuhap.id/?p=917, diakses tanggal 23 Nopember 2018. 
sidang mengangkat orang yang pandai bergaul dengan terdakwa atau saksi tersebut sebagai penerjemah."

Pasal 168 ayat (2) berbunyi: "Jika terdakwa atau saksi bisu atau tuli tetapi dapat menulis, Hakim Ketua sidang menyampaikan semua pertanyaan atau teguran secara tertulis kepada terdakwa atau saksi tersebut untuk diperintahkan menulis jawabannya dan selanjutnya semua pertanyaan serta jawaban harus dibacakan."

Pengaturan di dalam dua pasal dalam RKUHAP tersebut hanya mengatur ketentuan pada proses pemeriksaan di muka persidangan saja. Sedangkan, pada tingkat penyidikan dan pra penuntutan, hak penyandang disabilitas belum diatur dan tidak terakomodir dengan jelas. Kondisi yang demikian tentu tidak memberikan keadilan bagi para penyandang disabilitas yang berperan aktif dalam upaya penegakan hukum.

\section{Konsekwensi Belum Disahkannya Peraturan Pemerintah Sebagai Aturan Pelaksana UU Penyandang Disabilitas}

Selama dua tahun sejak UU Penyandang Disabilitas 2016 disahkan, masyarakat terus mendesak pemerintah untuk segera menerbitkan peraturan pemerintah (PP) sebagai turunan Undang-Undang Nomor 8 Tahun 2016 tentang Penyandang Disabilitas. Hal ini karena, UU Penyandang Disabilitas belum bisa diimplementasikan secara optimal karena kententuan aturan pelaksanaan UU tersebut belum ada.

Terkait dengan belum disahkannya aturan pelaksanaan (Peraturan Pemerintah/PP) atas UU Disabilitas, tentu saja membawa konsekwensi, meski Undang-undang tersebut tetap dibisa dilaksanakan namun hal-hal tertentu yang bersifat teknis dan pengaturan yang lebih spesifik tidak akan bisa diterapkan, sementara hukum acara tetap berjalan.

Konsekwensi yang kemudian muncul sebagai dampak dari ketiadaan aturan pelaksana atas UU Penyandang Disabilitas adalah, tidak terjaminnya kepastian hukum bagi para penyandang disabilitas, tidak dapat ditegakkannya aturan riil yang terkandung didalam pasal-demi-pasal UU yang dimaksud, dan lahirnya celah hukum yang dapat memicu para oknum untuk membuat kebijakan yang tidak tepat sehingga berpotensi tidak terpenuhinya hak-hak bagi penyandang disabilitas sebagaimana telah diatur dalam UU Penyandang Disabilitas 2016.

Berikut, hak-hak bagi penyandang disabilitas yang diatur secara khusus dalam Pasal 5 UU RI No 8 Tahun 2016, demi perlindungan dan pemenuhannya sesuai dengan kekhususan atas kondisi dan kebutuhan yang dimiliki, yaitu : hak- hak penyandang disabilitas, hak perempuan penyandang disabilitas dan hak anak penyandang disabilitas, sebagai berikut :

Hak penyandang disabilitas secara umum meliputi hak hidup, hak bebas dari stigma, hak privasi, hak keadilan dan perlindungan hukum, hak pendidikan, hak pekerjaan, kewirausahaan, dan koperasi, hak kesehatan, hak politik, hak keagamaan, hak keolahragaan, hak kebudayaan dan pariwisata, hak kesejahteraan sosial, hak aksesibilitas, hak pelayanan publik, hak pelindungan dari bencana, hak habilitasi dan rehabilitasi, hak konsesi, hak pendataan, hak hidup secara mandiri dan dilibatkan dalam masyarakat, hak berekspresi, berkomunikasi, dan memperoleh informasi, hak berpindah tempat dan kewarganegaraan; dan bebas dari tindakan diskriminasi, penelantaran, penyiksaan, dan eksploitasi.

Selain hak penyandang disabilitas sebagaimana dimaksud diatas, bagi perempuan penyandang disabilitas memiliki hak atas kesehatan reproduksi, hak menerima atau menolak penggunaan alat kontrasepsi, hak mendapatkan pelindungan lebih dari perlakuan diskriminasi berlapis, hak untuk mendapatkan pelindungan lebih dari tindak kekerasan, termasuk kekerasan dan eksploitasi seksual.

Khsus untuk anak penyandang disabilitas juga memiliki hak mendapatkan pelindungan khusus dari diskriminasi, penelantaran, pelecehan, eksploitasi, serta kekerasan dan kejahatan seksual, hak mendapatkan perawatan dan pengasuhan keluarga atau keluarga 
pengganti untuk tumbuh kembang secara optimal, hak dilindungi kepentingannya dalam pengambilan keputusan, hak perlakuan anak secara manusiawi sesuai dengan martabat dan hak anak, hak Pemenuhan kebutuhan khusus, hak perlakuan yang sama dengan anak lain untuk mencapai integrasi sosial dan pengembangan individu; dan hak mendapatkan pendampingan sosial.

Selain pengaturan hak-hak tersebut, didalam UU Penyandang Disabilitas 2016, setidaknya terdapat 14 pasal terkait dengan hakhak bagi penyandang disabilitas dan bagi pihak pendukung disabilitas yang terancam pemenuhan haknya karena belum adanya aturan pelaksana, yaitu :

Berikut pasal-pasal yang mengatur mengenai kewajiban Pemerintah dan Pemerintah Daerah beserta ketentuan mengenai sanksi administratif :

Pasal 27 : Pemerintah dan Pemerintah Daerah wajib melakukan perencanaan, penyelenggaraan, dan evaluasi tentang pelaksanaan Penghormatan, Pelindungan, dan Pemenuhan hak penyandang disabilitas.

Pasal 36 : Lembaga penegak hukum wajib menyediakan akomodasi yang layak bagi penyandang disabilitas dalam proses peradilan.

Pasal 42 : Penyelenggara Pendidikan Tinggi yang tidak membentuk Unit Layanan Disabilitas (ULD), diberi sanksi administratif yang diatur dengan Peraturan Pemerintah.

Pasal 43 : Pemerintah dan Pemerintah Daerah wajib memfasilitasi lembaga penyelenggara pendidikan dalam menyediakan akomodasi yang layak dan apabila tidak dilaksanakan makan akan dikenakan sanksi administratif.

Pasal 54 : Pemerintah dan Pemerintah Daerah wajib memberikan insentif kepada perusahaan swasta yang mempekerjakan penyandang disabilitas.
Pasal 55 : Pemerintah Daerah wajib memiliki Unit Layanan Disabilitas pada dinas yang menyelenggarakan urusan pemerintahan daerah di bidang ketenagakerjaan.

Pasal 86 : Pemerintah dan Pemerintah Daerah wajib memberikan insentif kepada perusahaan pariwisata menyelenggarakan jasa perjalanan wisata yang mudah diakses oleh penyandang disabilitas.

Pasal 109 : Pemerintah dan Pemerintah Daerah wajib mengambil langkah yang diperlukan untuk menjamin penanganan

Penyandang Disabilitas pada tahap prabencana, saat tanggap darurat, dan pascabencana.

Pasal 114 : Pemerintah dan Pemerintah Daerah wajib memberikan Konsesi untuk Penyandang Disabilitas.

Berikut pasal-pasal yang pelaksanaan lebih lanjutnya diatur dengan Peraturan Pemerintah Pasal 96 : Ketentuan lebih lanjut mengenai rehabilitasi sosial, jaminan sosial, pemberdayaan sosial, dan perlindungan sosial.

Pasal 104 : Pemerintah dan Pemerintah Daerah memfasilitasi permukiman yang mudah diakses oleh penyandang disabilitas.

Pasal 108 : Pelayanan publik yang mudah diakses oleh penyandang disabilitas diatur dengan Peraturan Pemerintah.

Pasal 113 : Ketentuan lebih lanjut mengenai layanan habilitasi dan rehabilitasi diatur dengan Peraturan Pemerintah.

Pasal 116 : Pemerintah dan Pemerintah Daerah memberikan insentif bagi perusahaan swasta yang memberikan Konsesi untuk Penyandang Disabilitas.

Kewajiban-kewajiban bagi Pemerintah dan Pemerintah Daerah sebagaimana tersebut 
diatas, tentu saja melahirkan hak bagi penyandang disabilitas dan disertai dengan sanksi yang mengikutinya, namun dengan belum adanya peraturan pelaksanaannya maka ke-9 aturan tersebut menjadi mandul dan tidak dapat dijalankan, begitu juga atas ke-5 pasal lainya menjadi tidak memiliki kekuatan mengikat.

\section{Penutup}

Ragam penyandang disabilitas dalam UU Penyandang Disabilitas 2016, diatur lebih spesifik apabila dibandingkan dengan klasifikasi disabilitas dalam Convention on The Rights of Persons With Disabilities (Konvensi Mengenai Hak-Hak Penyandang Disabilitas). Dimana pada pembukaan huruf (i) konvensi tersebut hanya menyatakan "Mengakui pula keragaman penyandang disabilitas", tanpa ada penjabaran mengenai macam atau ragam penyandang disabilitasnya. Pengaturan dalam konvensi masih bersifat normatif, terlalu fokus pada kewajiban negara untuk menerapkan prinsipprinsip dan hak-hak bagi penyandang disabilitas. Sementara UU No. 19 tahun 2011 pun belum secara implementatif dapat menjamin pemenuhan, perlindungan dan penghormatan hak-hak penyandang disabilitas, sehingga diperlukan adanya regulasi aturan yang memandatkan aparatur negara menjamin pelaksanaan hak disabilitas, pengawasan implementasi hak, ketentuan dan sanksi.

Hal-hal mana yang sebenarnya telah diatur didalam UU Penyandang Disabilitas 2016, namun karena lambatnya pengesahan aturan pelaksanaan atas UU tersebut, mengakibatkan timbulnya konsekwensi yang berkepanjangan bagi Pemerintah dan Pemerintah Daerah, dan terlanggarnya hak-hak penyandang disabilitas seta pihak pendukung disabilitas. Berdasarkan uraian tersebut, beberapa kesimpulan dan saran yang dapat peneliti kemukakan, adalah sebagai berikut :

\section{Kesimpulan}

a. Bertolok ukur dari sikap dan cara pandang masyarakat, termasuk didalamnya para Aparat Penegak Hukum yang masih menganggap penyandang disabilitas sebagai kelompok yang lemah, ditegaskan pula dengan belum terakomodirnya kebutuhan para penyandang disabilitas yang berperan aktif dalam penegakan hukum termasuk dalam posisinya sebagai saksi, namun tidak di tunjang dengan fasilitas-fasilitas yang ramah disabilitas dan bersifat aksesibel dalam bentuk ketersediaan alat media, sarana, dan prasarana yang dibutuhkan dalam proses persidangan, termasuk sejak pada tahap penyidikan dan tahap-tahap awal lainnya, menunjukkan bahwa Pemerintah, Aparat dan Institusi Penegak Hukum belum siap dalam Mewujudkan Hukum yang Berkeadilan Bagi Para Penyandang Disabilitas.

b. Bahwa Undang-Undang Penyandang Disabilitas 2016 telah sah diberlakukan sejak diundangkan 2 tahun silam, meski belum diikuti dengan aturan pelaksanaannya yaitu Peraturan Pemerintah (PP). Ketiadaan aturan pelaksana atas UU Disabilitas menimbulkan dampak tidak terjaminnya kepastian hukum bagi para penyandang disabilitas, tidak dapat ditegakkannya aturan riil yang terkandung didalam pasaldemi-pasal UU Disabilitas, dan lahirnya celah hukum yang dapat memicu para oknum untuk membuat kebijakan yang tidak tepat sehingga berpotensi tidak terpenuhinya hak-hak bagi penyandang disabilitas. Hal ini sangat berpotensi besar menimbulkan pelanggaran Hak Asasi bagi para penyandang disabilitas dan para pihak pendukung disabilitas.

2. Saran

a. Demi mewujudkan hukum yang berkeadilan bagi penyandang disabilitas, sebaiknya pemerintah segera menyiapkan fasilitas-fasilitas yang ramah disabilitas dan bersifat aksesibel dalam bentuk ketersediaan alat media, sarana, dan prasarana yang dibutuhkan sejak tahap penyidikan hingga proses persidangan, yang diatur dalam regulasi yang jelas dan mengikat. Serta menyelenggarakan pelatihan-pelatihan demi membekali para pegawai pelaksana yang bekerja dibidang penyelenggaraan hukum termasuk polisi, pengawal tahanan dan sipir penjara, 
dengan keterampilan dan skill khusus, guna mengakomodir kebutuhan penyandang disabilitas sehingga dapat terintegrasi dengan sistem hukum acara peradilan pidana.

b. Dalam rangka mewujudkan kepastian hukum bagi para penyandang disabilitas, Pemerintah harus segera mengesahkan aturan pelaksana (Peraturan Pemerintah/PP) atas UU Penyandang Disabilitas 2016, sehingga memperkecil resiko pelanggaran Hak Asasi bagi penyandang disabilitas dan dapat mengapresiasi pihak pendukung disabilitas yang beritikat baik.

\section{DAFTAR PUSTAKA}

Buku

Eddyono, Supriyadi Widodo dan Kamilah, Ajeng Gandini, (2015). Aspek - Aspek Criminal Justice Bagi Penyandang Disabilitas, Jakarta : Institute for Criminal Justice Reform.

Nawawi Arief, Barda, (2007). Perkembangan Sistem Pemidanaan di Indonesia. Semarang : Pustaka Magister.

Muladi, (1995). Kapita Selekta Sistem Peradilan Pidana. Semarang : Badan Penerbit Universitas Diponegoro.

Nursyamsi, Fajri \& Arifianti, Estu Dyah, Muhammad Faiz Aziz, Putri Bilqish dan Abi Marutama, (2015). Kerangka Hukum Disabilitas di Indonesia : Menuju Indonesia Ramah Disabilitas, Jakarta : Pusat Studi Hukum dan Kebijakan Indonesia.

Soekanto dan Abdurrahman, H., (2003). Metode Penelitian Hukum, Jakarta : Rineka Cipta.

\section{Jurnal}

Hamidi, Jazim, (2016). Perlindungan Hukum terhadap Disabilitas dalam Memenuhi Hak Mendapatkan Pendidikan dan Pekerjaan, Jurnal Hukum Quia Iustum, Vo. 23 Issue 4.

Harahap, Rahayu Repindowaty \& Bustanuddin, (2015). Perlindungan Hukum Terhadap Penyandang Disabilitas Menurut
Convention On The Rights Of Persons With Disabilities (CRPD), Jurnal Inovatif, Volume VIII Nomor I.

Purwadi, M., (2018). Penguatan Akses Hukum dan Pengadilan, Majalah Komisi Yudisial, Edisi April-Juli 2018.

Suhartoyo, (2014). Perlindungan Hukum Terhadap Pekerja/Buruh Penyandang Disabilitas Di Indonesia, MasalahMasalah Hukum, Jilid 43 No. 4.

Tyesta, Lyta, (2015). Prespek Perlindungan Penyandang Disabilitas Terhadap Perilaku Diskriminatif Di Kota Semarang, Masalah-Masalah Hukum, Jilid 44 No. 3.

\section{Peraturan Perundang-Undangan}

Convention On The Rights of Persons With Disabilities 2008.

Undang-Undang Dasar Negara Republik Indonesia Tahun 1945.

Undang-Undang Negara Republik Indonesia Nomor 19 Tahun 2011 tentang Pengesahan Convention On The Rights of Persons With Disabilities.

Undang-Undang Nomor 8 Tahun 2016 tentang Penyandang Disabilitas.

Undang-Undang No. 4 Tahun 1997 tentang Penyandang Cacat.

Undang-Undang No. 39 Tahun 1999 tentang Hak Asasi Manusia

Peraturan Pemerintah No. 43 Tahun 1998 tentang Upaya Peningkatan Kesejahteraan Sosial Penyandang Cacat.

\section{Artikel (Internet)}

Dharma, Avicena Farkhan, (2018). Kompas.com., https://olahraga.kompas.com/read/2018/09 /04/14410008/sejarah-penyelenggaraanasian-para-games, diakses tanggal 22 Nopember 2018.

Editor, (2014). RUU KUHAP Belum Penuhi Hak Penyandang Disabilitas, Kompas.com., http://pantaukuhap.id/?p=917., diakses tanggal 23 Nopember 2018.

Linksos, Admin, (2017). Difabel Wajib Tahu, Inilah Hak- hak Penyandang Disabilitas. Sebarkan!, https://lingkarsosial.wordpress.com/2017/ 
06/20/difabel-wajib-tahu-inilah-hak-hak-

penyandang-disabilitas-sebarkan/, diakses tanggal 22 Nopember 2018.

Sucipto, Purnomo, (2015). Mengapa UndangUndang Perlu Peraturan Pelaksanaan?, http://setkab.go.id/mengapa-undangundang-perlu-peraturan-pelaksanaan/, diakses tanggal 22 Nopember 2018.

Winata, Dhika Kusuma, (2017). Media Indonesia, Penerbitan PP soal Disabilitas Mendesak, http://mediaindonesia.com/read/detail/135 883-penerbitan-pp-soal-disabilitasmendesak, diakses tanggal 22 Nopember 2018.

WRC, Mitra Wacana, (2016). https://mitrawacana.or.id/berita/undangundang-republik-indonesia-nomor-8-tahun2016-tentang-penyandang-disabilitas/, diakses tanggal 22 Nopember 2018. 